Swarthmore College

Works

Spring 2014

\title{
Lesson Plan For Teaching Flannery O'Connor's "A Good Man Is Hard To Find"
}

Adriana M. Obiols Roca , '16

Peter Schmidt

Swarthmore College, pschmid1@swarthmore.edu

Follow this and additional works at: https://works.swarthmore.edu/fac-english-lit

Part of the English Language and Literature Commons

Let us know how access to these works benefits you

\section{Recommended Citation}

Adriana M. Obiols Roca , '16 and Peter Schmidt. (2014). "Lesson Plan For Teaching Flannery O'Connor's "A Good Man Is Hard To Find"'". English Literature Faculty Works. DOI: 10.24968/2476-2458.engl.351

https://works.swarthmore.edu/fac-english-lit/351

\section{(c) (1) (8)}

This work is licensed under a Creative Commons Attribution-Noncommercial 4.0 License

This work is brought to you for free by Swarthmore College Libraries' Works. It has been accepted for inclusion in English Literature Faculty Works by an authorized administrator of Works. For more information, please contact myworks@swarthmore.edu. 


\section{Lesson Plan for teaching Flannery O'Connor's short story "A Good Man is Hard to Find" \\ by Adriana Obiols Roca '16 / Swarthmore College Spring 2014}

a project completed for Prof. Peter Schmidt's

English 71D, “The Short Story in the U.S.” Swarthmore College

\section{$\underline{\text { Table of Contents }}$}

- the lesson plan itself (pp. 1-11)

- discussion of the plan (pp. 11-14)

- a set of Web links useful for the lesson (p. 14-15)

Objectives: students will ...

- Understand the differences between direct and indirect characterization and be able to identify examples of each.

- Understand the uses of irony and foreshadowing in the story as well as more generally in literature.

- Become acquainted with Flannery O'Connor and her writing style, particularly with her use of the grotesque.

- Explore the complexity of the themes present in the story and the characters O’Connor has created, especially the Misfit and the grandmother.

- Exercise a variety of critical thinking and analytical skills in order to form ideas and opinions about O'Connor's story and her writing strategies.

- Practice reading comprehension and summarization.

- Employ and practice writing skills in an essay assignment.

Necessary preparation: 
The teacher should have familiarized him or herself with Flannery O'Connor's life and work before the lesson by using the links provided below. It is also important that the teacher review definitions of the terms characterization, irony, and foreshadowing (see below).

Students are expected to have read Flannery O'Connor's “A Good Man is Hard to Find" as well as her essay "Some Aspects of the Grotesque in Southern Fiction" (1960). This lesson plan is designed to be split into two days of class, but if the teacher judges that not all the material is necessary or that it can be covered in one period, the lesson plan can be done in one day.

\section{Introductory activity - Day 1:}

For today the students should have read both O'Connor's story “A Good Man is Hard to Find" and her essay on the grotesque. This day, the class will focus around O'Connor's essay on the grotesque. The teacher should begin the class by presenting biographical information about Flannery O'Connor. Then, through analysis of the essay, the class should arrive together at a definition of the grotesque both in the general sense of the word and as it pertains to O'Connor's writing. The teacher should write down the key ideas that the class comes up with on the board to compile them.

It may be helpful to consider the following passages; the questions that follow can be used to spark discussion:

- "Today many readers and critics have set up for the novel a kind of orthodoxy. They demand a realism of fact which may, in the end, limit rather than broaden the novel's scope. They associate the only legitimate material for long fiction with the movement of social forces, with the typical, with fidelity to the way things look and happen in normal life. (...) In these grotesque works, we find that the writer has made alive some experience which we are not accustomed to observe every day, or which the ordinary man may never experience in his ordinary life. We find that connections which we would expect in the customary kind of realism 
have been ignored, that there are strange skips and gaps which anyone trying to describe manners and customs would certainly not have left. Yet their characters have an inner coherence, if not always a coherence to their social framework. Their fictional qualities lean away from typical social patterns, toward mystery and the unexpected."

Discussion Questions: How does the type of realism that, according to O'Connor, critics demand contrast with the realism that she portrays in "A Good Man Is Hard to Find"? How is it realistic? Especially considering that, as she puts it, "escaped criminals do not roam the roads exterminating families, nor Bible salesmen prowl about looking for girls with wooden legs."

- "If the novelist is in tune with this spirit, if he believes that actions are predetermined by psychic make-up or the economic situation or some other determinable factor, then he will be concerned above all with an accurate reproduction of the things that most immediately concern man, with the natural forces that he feels control his destiny. (...) On the other hand, if the writer believes that our life is and will remain essentially mysterious, if he looks upon us as beings existing in a created order to whose laws we freely respond, then what he sees on the surface will be of interest to him only as he can go through it into an experience of mystery itself. His kind of fiction will always be pushing its own limits outward toward the limits of mystery, because for this kind of writer, the meaning of a story does not begin except at a depth where adequate motivation and adequate psychology and the various determinations have been exhausted. Such a writer will be interested in what we don't understand rather than in what we do. He will be interested in possibility rather than in probability. He will be interested in characters who are forced out to meet evil and grace and who act on a trust beyond themselves-whether they know very clearly what it is they act upon or not."

Discussion Questions: How does this interest in "possibility rather than in probability" help set up an atmosphere of ambiguity in O'Connor's story? What 
makes this ambiguity valuable? How is this ambiguity and mystery connected to "A Good Man is Hard to Find", particularly the ending?

- "Whenever I'm asked why Southern writers particularly have a penchant for writing about freaks, I say it is because we are still able to recognize one. To be able to recognize a freak, you have to have some conception of the whole man, and in the South the general conception of man is still, in the main, theological. That is a large statement, and it is dangerous to make it, for almost anything you say about Southern belief can be denied in the next breath with equal propriety. But approaching the subject from the standpoint of the writer, I think it is safe to say that while the South is hardly Christ-centered, it is most certainly Christhaunted. The Southerner, who isn't convinced of it, is very much afraid that he may have been formed in the image and likeness of God. Ghosts can be very fierce and instructive. They cast strange shadows, particularly in our literature. In any case, it is when the freak can be sensed as a figure for our essential displacement that he attains some depth in literature."

Discussion Questions: How is O'Connor's view of the grotesque connected to her faith? Her idea of an "essential displacement" points to a belief that humanity is in in a "fallen" (in a Christian sense) state. How is this related to the "realism" that she claims to reveal? Does she link our real grotesqueness with her belief in fallen humanity? How do the characters in the story reflect this? Consider also the paradox posed by the fact that the Misfit, an outcast and a criminal, and the Grandmother, who believes herself to be an exemplary person, are both portrayed as grotesque.

- "And [the reader's] need, of course, is to be lifted up. There is something in us, as storytellers and as listeners to stories, that demands the redemptive act, that demands that what falls at least be offered the chance to be restored."

Discussion Questions: How does this idea of possibility for redemption expand the definition of the grotesque in O'Connor's work? Additionally, consider this passage in relation to the ending of "A Good Man is Hard to Find." Do you think 
the Grandmother's touching the Misfit and asserting that she is a good man signal that the Misfit can be redeemed? vIn this light, what might his disturbed reaction mean?

- "The problem for such a novelist will be to know how far he can distort without destroying, and in order not to destroy, he will have to descend far enough into himself to reach those underground springs that give life to big work."

\section{Development activity - Day 2:}

This day, the class will focus around formal aspects of writing as applied to the story. The teacher should define the relevant terms. Definitions are provided below, but their employment is left at the teacher's discretion:

Characterization (kar-ik-ter-uh-zaY-shun): the means through which an author reveals a character's personality. Characterization may be direct or indirect. In direct

characterization, the writer or a narrator tells the reader what the character is like: "ben was a quiet, serious boy." in indirect characterization, the author shows the reader or audience member what the character is like through (1) how the character looks, (2) what the character does, (3) what the character says, (4) what the character thinks, and (5) how the character affects other characters. From these five things, the reader or audience member understands the character's personality.

Foreshadowing (for-Shad-oh-ing): Clues or hints about something that is going to happen later in the story. Authors use foreshadowing to build suspense and to prepare the reader for what happens later.

Irony (ahY-ruh-nee): there are three types of irony: (1) dramatic irony, when the reader or audience member is aware of something that the characters are not aware of; (2) situational irony, when something happens that is the reverse of what you expected; and (3) verbal irony, when the name or description of something implies the opposite of the truth (for example, calling a very tall person "tiny").

(from Scope Magazine's Glossary of Literary Terms) 
Then, the teacher should ask the entire class some of the introductory level questions, which relate to the concepts previously defined, in order to get the discussion started. The students should subsequently be divided into groups to work on middle level and concluding questions. The way the groups are to be formed and the questions divided is not particularly specific and is left at the teacher's discretion; there can be multiple groups working on the same question or (depending on class size) larger groups working on one question each, or small groups with the freedom to choose the questions that most interest them. The class should then reconvene and individual groups should briefly relate the most important points that came up in their conversation. This is also an opportunity to open up the discussion of middle level and concluding lessons to the class as a whole and for the teacher to provide guidance where needed. It should be made clear to students that the questions are meant to provide direction for their discussion but they are not meant to be constricting and it is not necessary that they answer every point the questions bring up, especially with the middle and concluding level questions. This is because this gives students the freedom to explore the aspects that most interest them about the story and their discussion of it. However, they are also required to analyze their chosen topics carefully and meaningfully.

\section{Discussion questions:}

\section{Introductory level}

- What moments in the story can be characterized as ironic or seem to foreshadow the events of the plot? Think particularly about the grandmother's comments and passages in the beginning of the story, such as "...they left Atlanta at eight fortyfive with the mileage on the car at 55890. The grandmother wrote this down because she thought it would be interesting to say how many miles they had been when they got back." (553)

- Notice the direct and indirect characterization O'Connor uses throughout the story. How does it contribute to our perception of the characters? What about them is grotesque and exaggerated? A good place to start is the character descriptions toward the beginning of the story. 
- Which strategies does O'Connor use in the beginning of the story in order to set up a believable and plausible setting? What kinds of details make the time and place one that we can easily imagine? Do you think the characters and the plot are believable? How then does the normalcy and immediacy of the setting contrast with the rest of the story, and what effect does it have on the story overall?

\section{Middle level}

- Discuss the characters' different reactions to the car accident in pages 558 to 559. Are their reactions believable in the context of the story and based on what we know about each character? Which strategies does O'Connor use to make these characters so consistent and why is it important that she do so? What does it contribute to the story?

- Would you characterize the ending of the story as hopeful or pessimistic? Why?

- How does the Misfit justify his actions? Look closely at the following passages:

○ "'What did you do to get sent to the penitentiary that first time?' (...)'I forget what I done, lady, I set there and set there, trying to remember what it was I done and I ain't recalled it to this day."' (562-563)

- "'I found out the crime don't matter. You can do one thing or you can do another, kill a man or take a tire off his car, because sooner or later you're going to forget what it was you done and just be punished for it."' (563)

○ ' 'I call myself The Misfit,' he said, 'because I can't make what I done wrong fit what all I gone through in punishment.'" (564)

- "'Does it seem right to you, lady, that one is punished a heap and another ain't punished at all?"' (564)

\section{Concluding}

- Why do you think the Misfit was so disturbed by the grandmother's touch in pg. 565 ? Is the moment in which she calls him one of her own sons actually a moment of sudden realization of truth? What triggers it for the grandmother? Is it 
an act of grace and kindness? If you have interpreted it as such, how does this final act of grace and truth contrast with what the Misfit describes as being the best way to spend the last few moments of your life (page 564)? Why does the grandmother reach out to him like that? Is it consistent or inconsistent with her earlier behavior toward others?

- Notice the way the Misfit talks about Jesus in page 564 and how he seems to, in some ways, identify with him. Note also the way that, when she responds to the Misfit, it is grammatically possible that the grandmother is calling him "Jesus". Additionally, consider the importance of the deeply religiously charged sentence “you've got good blood" (564) (as it relates to Christian doctrine and the idea that Jesus' blood can bring absolution from sin). Do you believe this interpretation is plausibly suggested in the story? If so, how should we understand it? How does it inform our comprehension of the Misfit and the reasons for his actions? Think especially about Jesus' and the Misfit's relationship with sin and punishment. (NOTE: This question might need some clarification, depending on the students' religious background and knowledge. If necessary, the teacher should be prepared to provide it.)

- How can we interpret the Misfit's last sentence - "It's no real pleasure in life" (565) - in conjunction with the sentence "No pleasure but meanness" (564) in the previous page?

- Consider the title of the story; "A Good Man is Hard to Find". Should we understand this as a general statement of truth? Who might be making this assertion? Are there any good men in the story? If there are, who are they? What makes them good? If there aren't, what makes all of the men in this story bad men?

\section{Closure activity:}

Students will be assigned a short analytical paper (4-5 pages long) on the story. In it, they must construct a thesis in answer to one of the questions discussed in class. If a student were to express a strong preference to pursue a thesis on a topic that was not covered in class, she should confer with the teacher for approval before proceeding. Alternatively, 
students may write a response to the article "Flannery O'Connor's validation of the unreasonable in 'A Good Man is Hard to Find"' by John V. McDermott. The essay deals with the "mystery" that O'Connor talks about in "Some Aspects of the Grotesque in Southern Fiction". McDermott looks particularly at the atmospheric paradoxes O'Connor sets up near the end of the story to make assertions about the Misfit and the Grandmother and how they are related to O'Connor's idea of mystery. The essay applies the concepts from O'Connor's own essay to “A Good Man is Hard to Find” specifically, so it is a good way to further engage with the material covered.

\section{Discussion of the Lesson Plan for Flannery O'Connor's "A Good Man is Hard to Find," by Adriana Obiols Roca '16 / Swarthmore College}

A project completed for Prof. Peter Schmidt's

English 71D, “The Short Story in the U.S.” Swarthmore College, Fall 2014

The objectives stated in the lesson plan cover a number of skills that students are expected to gain or employ during the class and in the completion of reading and homework assignments. Some of these goals are specific and content-related, while others focus on the development of broader abilities. First are the objectives related to learning the literary terms of direct and indirect characterization, irony, and foreshadowing. It is important that students not only learn the definitions of these concepts - which are typically taught in high school English classes - but that they are able to see them applied and that they learn to recognize them in writing. The story is used in this lesson to illustrate the use of these terms so that they do not remain vague and abstract ideas.

Second are the goals relating to Flannery O'Connor specifically as a writer. Students should be exposed to the work of famous and important authors both to become 
more cultured persons and to familiarize themselves with a variety of different writing styles and cultivate an appreciation for them. Flannery O'Connor's style is very distinctive and complex, and the characters she has created in this story are deceptively simple. Approaching her work in a class setting allows for the dissection and exploration of her writing. The emphasis on her use of the grotesque, which is one of the most important and particular characteristics of her style, provides students with a clear way to identify O'Connor's prose should they encounter it again and allows them to draw connections between her and other authors that may use similar techniques.

The application and development of critical thinking and analytical skills are also important goals of this lesson. These kinds of skills are useful for the critical examination of literature and texts in general, a valuable ability that will undoubtedly be required of students later, especially as they prepare for higher education. Entering discussions in which they must employ analytical skills is also beneficial for students because they must naturally present original ideas, which creates opportunities for them to understand the text from a variety of approaches. Listening to their classmates' points of view and focusing on specific aspects of the story compels them to think about the story from different angles. They will, quite literally, discover what is so good about O'Connor's “A Good Man is Hard to Find". Finally, the objectives pertaining to reading comprehension, summarization, and writing skills are important because all of these abilities enable students to further exercise critical thinking as well as prove their capacity to express ideas coherently orally and in writing.

The introductory activity is structured in a way that allows for the participation of the whole class in the creation of definitions that will be used subsequently throughout 
the lesson. Since some of these definitions will be based upon the article "Grace and the Grotesque: Flannery O'Connor on the page and the screen" by Jon M. Sweeney, which is required reading for the class, the students will need to draw upon and demonstrate their reading comprehension and summarization skills. Using both the article and the story to identify some of the fundamental qualities of O'Connor's fiction also creates opportunities for them to display their individual understanding of the writing techniques she uses. The emphasis placed on students' contributions to the definition of concepts that will be useful later in the lesson is also based on the notion that recognizing students' ideas as valuable, valid and important is crucial to the development of a positive classroom environment in which student to teacher relationships are not unilateral or hierarchical.

Two of the introductory level questions from the developmental activity are directly related to the material that was covered in the introductory activity and therefore serves as a smooth way to transition from the beginning of the lesson to the discussion portion of the class. The questions ask that students apply the concepts previously defined to the story specifically, which inherently requires that they comprehend the terms with sufficient depth to be able to recognize their use in "A Good Man is Hard to Find". With the help of the teacher's guidance, the connection between the content and its real application is made clear and explicit. The last introductory question is less grounded on specific terms and focuses on broader features of the story, and as such provides a transition to the middle level and concluding questions, which delve into deeper aspects of the plot and of characters' personalities. The subsequent division of the class into small discussion groups for students to work on middle level and concluding questions is 
due to the fact that it allows each group much more freedom to converse than a wholeclass discussion would. Students generally feel more comfortable voicing their opinions in smaller groups and the contained nature of the discussion allows them to reply to each other's ideas without having to wait for a turn to speak, encouraging them to engage in thought-provoking discussion grounded on critical thinking. Additionally, it provides them the flexibility to explore interesting avenues of thought that might seem tangential in a whole-class discussion. The middle and concluding questions ask students to think critically about characters' actions and motivations and are more focused than the introductory questions. They require insightful analysis and encourage the students to truly take in and appreciate the complexity and depth of the characters and the themes in O'Connor's story. The reason why the class later reconvenes is that it is useful for students to learn from each other and listen to their classmates' ideas. By sharing, the teacher and the students may come to understand "A Good Man is Hard to Find" in new and exciting ways, generating and refueling discussion for the class as a whole. In conveying their ideas to their classmates, students must also make effective use of summarization skills.

The closure activity, a short essay, is meant to provide an opportunity for students to express in formal writing the ideas that were the most stimulating or exciting for them. It demands originality and critical analysis as well as the ability to expand on ideas that originally formed during class discussion. In the assignment students will demonstrate their understanding of O'Connor's story and express their opinions and theories about it. Providing a wide range of options for the students to choose from for the essay prompt in addition to the possibility of creating an entirely new prompt gives students the freedom 
to explore aspects that truly interest them about the story while still offering a certain degree of direction and focus. The assignment is also meant to help develop students' writing skills, which are essential for academic success in all disciplines. Since the essay must be short, it must also be concise and to the point. Moreover, scoring will depend upon students' ability to effectively communicate their ideas in a coherent and appropriate manner.

\section{Links and Resources}

\section{Class materials:}

- Flannery O’Connor, "A Good Man is Hard to Find." In Major American Short Stories, Third Edition. Edited by A. Walton Litz. Published by Oxford University Press, 1994. O'Connor's story may be found in other anthologies as well.

- Flannery O'Connor reads "A Good Man is Hard to Find": http://www.mhpbooks.com/audio-flannery-oconnor-reads-a-good-man-is-hard-tofind/

- O'Connor's essay "Some Aspects of the Grotesque" may be found in her collection Mystery and Manners: Occasional Prose. Ed. Sally and Robert Fitzgerald. New York: Farrar, Straus, \& Girouz, 1969.

- Listen to O'Connor read and discuss parts of "Some Aspects of the Grotesque": http://www.openculture.com/2013/04/listen_as_flannery_oconnor_reads_some_as pects_of_the grotesque_in_southern_fiction_c_1960.html

- "Grace and the Grotesque: Flannery O'Connor on the page and the screen" by Jon M. Sweeney: http://americamagazine.org/issue/701/ideas/grace-and-grotesque

- "Flannery O'Connor's validation of the unreasonable in 'A Good Man Is Hard to Find"" by John V. McDermott:

http://go.galegroup.com/ps/i.do?id=GALE\%7CA231714517\&v=2.1\&u= swar94187\&it $=\mathrm{r} \& \mathrm{p}=\mathrm{LitRC} \& \mathrm{sw}=\mathrm{w} \& \mathrm{asid}=\mathrm{df1}$ e638d3a24ff18f825c05000 $\underline{527077}$

- Scholastic's Scope Magazine Glossary of Literary Terms http://www.scholastic.com/scopemagazine/PDFs/SCOPE-LibraryLiteraryTerms.pdf 
- Bedford St. Martin's' "LitGloss" glossary of literary terms http://bcs.bedfordstmartins.com/litgloss/

Biographical information about Flannery O'Connor:

- New Georgia Encyclopedia http://www.georgiaencyclopedia.org/articles/artsculture/flannery-oconnor-1925-1964

- The Biography Channel http://www.biography.com/people/flannery-oconnor$\underline{9426760}$ 